\title{
The Strategy of Enhancing Student's Social Awareness Through History Learning Based on Selimbur Caye Oral Tradition Values
}

\author{
Een Syaputra*; Sariyatun Sariyatun; Sunardi Sunardi \\ Department of History Education, Sebelas Maret University, Indonesia \\ Email: yung_een@yahoo.co.id
}

http://dx.doi.org/10.18415/ijmmu.v5i4.161

\begin{abstract}
This research aims to examine the implementation and effectiveness of history learning based on Selimbur Caye oral tradition values. This research uses mixed method approach. The subjects of this research are the student of X Social Science 1 (experimental class) and X Social Science 2 (control class) in SMA Negeri 4 South Bengkulu. The data of this study were collected using interview, observation, and documentation (qualitative phase) and questionaire (quantitative phase). They were, than, analyzed by using interactive model for qualitative data and t-test for the quantitative data. The result of this research are: 1) history learning based on Selimbur Caye oral tradition was conducted by combaining Problem Based Learning, Value Clarification Technique model, and the Values of Selimbur Caye oral tradition; 2) the implementation of history learning based on Selimbur Caye oral tradition is very efective in enhancing student's social awareness.
\end{abstract}

Keywords: Social Awareness; Oral Tradition; Problem Based Learning; Value Clarification Technique; History Learning;

\section{Introduction}

The rapid development of science, technology, information and communication in the global era has made impacts on the nations' state in the world, especially for developing country like Indonesia. The flow of globalization motivated by new knowledge of and super-sophisticated media technology has made the rate of information exchange between nations faster and dynamic, impacting the widespread contamination of certain cultures on other cultures (Boli \& Lechner., 2012: 554). Moreover, globalization will also encourage cultural imperialism or cultural homogeneity (Hannerz., 1990: 250, Sarikakis., 2001: 81), where humans are led to a way of thinking, which by Irwan Abdullah, called global thought (Abdullah., 2006: 167).

With such a situation, people are then faced with many choices of values so that it is feared there will be a shift in the value of local-national culture into a global culture. as revealed by Mubah (2011: 255) that globalization tends to solidify the existence of values coming from developed countries and get rid of traditional values in developing or poor countries culture. This is because the values of developed countries are considered modern and should be embraced, meanwhile, the values of developing countries 
are considered outdated and it needs to be abandoned. it is not surprising, then, that local sources which was being an inspiration for local social action have now been shifted to global sources (Abdullah., 2006: 167). the condition, then will result in the the local people's loss of experience and understanding of local culture as their national identity, (Sariyatun., 2014: 3).

In the context of social life, one of the real effects of the value shift is the declining social awareness of society. This is reflected in the phenomenon often happens lately, such as the collapse of cooperating culture, the weakening of social concern, the increasing attitude of individualism, or even criminal acts such as theft, murder, rape, and so forth.

Facing such problems, then, the role of education as a medium of values socialization becomes very important. Through which, social values as described above can be internalized in the learning process. By doing so, it is expected to form learners who have a high social awareness. As explained by Lickona (2012: 7) that one of the main goals of education is to form learners who have virtuous behavior. In the context of formal education in schools, especially high schools, history is one of the subjects that is full of value content, so it becomes very potential to be a medium in realizing learners as described above, (Wineburg., 2006: 6; Hasan., 2012: 87). As for the matter of social values, one of the potential historical sources to be exploited is the oral tradition as it contains many ideal values or moral teachings, especially with regard to social life. That way, it can be concluded that utilizing oral tradition as a basis for learning history is an important thing to do. Furthermore, the availability of oral tradition in Indonesia is abundant as each region has its own.

In the context of this study, the oral tradition we use as a basis is the oral tradition of Selimbur Caye, an oral tradition originating from the tribal community of Pasemah, Bengkulu, Indonesia. In this oral tradition of Selimbur Caye, there is a group of traditional expressions that contain the principles of social life or about how an individual positions himself in social interaction (Syaputra, Sariyatun, Sunardi., 2017: 234). therefore, through the implementation of historical learning based on the oral values of Selimbur Caye, learners will be guided towards the ideal values of society, such as social awareness and social sensitivity, responsibility, justice and honesty, deliberation and consensus, etc.

In the implementation, the internalization of Oral Selimbur Caye's oral tradition is carried out by combining Problem Based Learning model and Value Clarification Technique. The PBL model is a student-centered learning model, with teachers as facilitators and problems as the initial stimulus and workflow in learning, (Wilkerson \& Gijselaers., 1996: 101-102). Through the PBL Model, the learning that is carried out will be able to develop high-level thinking skills and the ability to think critically. Through the PBL Model, students learn to be aware of what they already know, what information they are talking about, and the strategies they must use to address the problem, (Winter., 2001:2). As for the context of history learning, PBL is very helpful in the process of material contextualization. In other words, the study of history, in which the study is about past events, can be drawn in relation to today's social problems.

As for the VCT, this model is one of the learning models that lead to the formation of attitudes and values. Sanjaya (2011: 283) argues that VCT is a teaching model that helps students in finding and determining the value that is considered good to deal with a problem. Furthermore, Rai (2014: 29) says that the main purpose of VCT is to help students to use their rational thinking and develop awareness, not only for forming their personal character but also forming social values they believe. In VCT, the process of attitudes and values construction is done systematically, ranging from choosing values, appreciating, to doing deeds based on the values chosen. In relation to the internalization of Selimbur caye oral tradition values, implementing VCT is the right thing to do since, through this model, the students are given the opportunity to directly choose the values that are considered good which will be appreciated and ultimately made the principles of acting. 


\section{Methodology}

This study used a mixed-method approach, an approach that combines qualitative and quantitative research techniques into one study (Creswel., 2003). Through the mixed method the conclusions of the study can show stronger evidence through convergence and corroboration (Johnson \& Onwuegbuzie., 2004: 21). This research was conducted in SMA Negeri 4 South Bengkulu, Bengkulu Province, Indonesia. The population in this study is the student of class X majoring in social science with the sample of class $X$ social science 1 and $X$ social science 2 with the total of 50 students.

In the first phase, this research uses qualitative method. The data are collected through interview, observation, and documentation. The aim is to gather the initial information about the values of Selimbur Caye oral tradition and the ongoing state of history learning which, then, will be used as the basis for designing learning strategies as what has been elucidated before.

In the second phase of the study, Quantitative research was conducted for testing hypotheses. The data collected using questionnaire. The respondents are 50 students; who were divided into two groups; experimental group (the class with history learning based on Selimbur Caye oral tradition value) and control group (the class with history learning taught using cooperative learning technique). All the data collected in this phase were analyzed using T-test.

\section{Discussion and Anlysis}

\subsection{Social Awarennes Aspects in Selimbur Caye Oral Tradition}

Based on the results of the research, it is found that the oral tradition of Selimbur Caye is a collection of traditional expressions containing social principles. There are twelve expressions contained in the Selimbur Caye oral tradition consisting of six suggestions and six abstentions. Table 1 shows contents of the Selimbur Caye oral tradition:

Table 1 Content and Meaning of the Selimbur Caye Oral Tradition

\begin{tabular}{|c|c|c|}
\hline No & Six Suggestions & Six Abstentions \\
\hline \multirow[t]{2}{*}{1.} & Seanak Bujang Seanak Gadis & Jangan Nube Ulu Mandian \\
\hline & One's child is everyone's child & $\begin{array}{l}\text { Don't attempt something that can harm } \\
\text { others. }\end{array}$ \\
\hline \multirow[t]{3}{*}{2.} & Ndepat Mbalik, Ngutang Mbayar, & Jangan Nutuh Dahan peninggighan \\
\hline & Semare Beghagih. & Don't bother other's privacy right. \\
\hline & $\begin{array}{l}\text { Give back the thing you found, pay } \\
\text { the debt you owed, share the } \\
\text { public property equally. }\end{array}$ & \\
\hline \multirow[t]{2}{*}{3.} & Sepincang Sepejalanan & Jangan Maraska Batu Keluagh \\
\hline & Many hands make ligh work. & Save someone face from the public. \\
\hline \multirow[t]{2}{*}{4.} & Seganti Setunggguan & Jangan Nyeghuti Jalan kayik \\
\hline & A friend in need is a friend indeed. & Don't abuse sanctity of the custom. \\
\hline \multirow[t]{2}{*}{5.} & Janji Nunggu Kate Betaruh & Jangan Ngunggung Pelidian \\
\hline & $\begin{array}{l}\text { A person should be a man of his } \\
\text { word. }\end{array}$ & Don't flee from responsibility. \\
\hline \multirow[t]{2}{*}{6.} & Seghepat Seghendi & Jangan Menghebe Pelaluan \\
\hline & Sportive in making agreement. & Don't destroy what belongs to public. \\
\hline
\end{tabular}

Source: Modified from Syaputra (2017) 
In addition, the values contained in Selimbur Caye's oral tradition can be identified as follows:

\section{Social Care}

Social care is the attitude that human beings as social beings cannot fulfill their own needs, and therefore among fellow human beings must pay attention to each other, help each other. In the oral tradition of Selimbur Caye, the value of social awareness can be found in expression "Seanak Bujang Seanak Gadis" (one's child is the child of society), and the expression "Sepincang Sepejalanan" and "Seganti Setungguan" (caring for comrades-in-arms).

\section{Democracy}

Regarding to democratic attitudes, the Pasemah people in Bengkulu has a principle known as "Seghepat Seghendi", means that an agreement of most votes. as revealed by Yasman (a local interviewee), that "Seghepat Seghendi" is an expression concerning attitude in performing a discussion, where we are guided or advised to openly accept mutual agreement/not to impose personal will (Interviewed with Respondent C, 10/8/2016).

\section{Honesty and Justice}

Being honest and doing justice are also two of the keys to realize of social harmony. Based on Selimbur Caye, the advice regarding honesty and justice is contained in the expression "Ndepat Mbalik, Ngutang Mbayar, Serame Beghagih". The intent in this expression is very clear, if we find something that is not ours, it should be returned to the rightful, if we has debt then it must be paid, and something possessed collectively must be divided equally_ do not cheat.

\section{Responsibility}

Responsibility means the ability to respond or answer. It means, the responsibilities are oriented among others, giving attention, and actively responding what they expect. Responsibility emphasizes the positive obligation to protect each other. Responsibility is an attitude of mutual need, not ignoring others who are in difficult circumstances. It is merely the property of everyone, or in other words that every individual will not be separated from responsibility, whether with respect to the God, to others, or to themselves. In the oral tradition of Selimbur Caye, there are three forms of responsibility mandated. First, the responsibility for counseling advises or reminds each other (see expression "seanak bujang seanak gadis"). Second, responsibility for words and appointments (see expression "janji nunggu kate betaruh"). Third, the responsibility regarding job (see expression "jangan ngunggung pelidian").

\section{Upholding or Respecting the Rights of Others}

Respect means show a respect for the dignity of others or thing other than ourselves. By having a high respect for the rights of others, one will be spared from behaviors that can harm others. There are several expressions in the oral tradition of Selimbur Caye containing suggestions for respecting or upholding the rights of others: 1) "jangan nube ulu mandian" and "jangan nutuh dahan peninggighan"respecting the rights of others in venture; 2) "jangan menghebe pelaluan"-regarding the rights of others to public facilities; 3) "jangan maraska batu keluagh" — do not throw responsibility to others. 


\section{Respect the Prevailing Customs}

Similar to respect for the rights of others customs prevailing in a society also require a respect. By having high respect for customs, obedience of customs will be realized. Regarding to respect for these customs, the doctrine contained in the Selimbur Caye oral tradition is represented in expression "jangan nyeghuti kayik", which is a prohibition for the Pasemah people to commit incest.

Based on the description above, it can be concluded that the oral tradition of Selimbur Caye contains some values such as social care, democracy, honesty, justice, responsibility, , upholding the other privacy rights, and custom respect. These values are essential values which existence is crucial and vital in the society life, as described in the previous section.

\subsection{Implmentation of History Learning Based on Selimbur Caye Oral Tradition Values}

As explained earlier, in its implementation, the internalization of Selimbur caye oral tradition values is done by combining PBL and VCT models. The PBL model, as expressed by Huda (2013: 272273) consists of six phases, namely: 1) problem presentation; 2) problem discussion; 3) independent study; 4) information sharing; 5) presentation of solutions to the problem; and 6) review. M eanwhile, The VCT model consists of three phases, namely: 1) selecting value; 2) appreciating value; and 3) acting, (Adisusilo, 2014: 147; Elmubarak, 2009: 72). Several phases in the PBL and VCT are, then, combined to become the following five stages of learning:

\subsubsection{Phase 1: Problems, Concepts and Values Presentation}

This phase is the first phase after the introduction phase. At this stage, the teacher begins the class by sharing brief essays or data on contemporary social issues (low social awareness) to be read and analyzed. After that, the teacher guides the students to relate it to the concept of social awareness and the value of Selimbur Caye's oral tradition. The objective is to shape students knowledge of concepts of problems, and values that will then be used as an analytical tool at the assessment stage. This stage then ends with an explanation of learning materials, learning objectives, learning steps to be undertaken, and then closed by motivational session.

\subsubsection{Phase 2: Organizing Students}

In this phase, the teacher divides the students into small groups, with members of each group of five to six people. After the group has been divided, the teacher provides directions on the tasks that each group will perform, and explanain the sub topic or the material will be discussed, the points that need to be discussed, the resources that can be used and the final report format.

\subsubsection{Phase 3: Conducting Assessment}

At this stage, students who have been organized into groups, conduct the assessments according to their respective subjects. The phase consists of three stages of activity, namely data exploration, analysis, and recommendation or problem solving. In the first phase, students collect the corresponding information of their respective subject, according to the sub-topic that has been explained previously. The information explored in this phase (in the context of this study) is about historical knowledge, such as socio-economic life of the people during the Aceh Kingdom, etc. (depending on the subject matter). The 
next stage is to perform data analysis by using the concept of social awareness contained in the Oral Tradition of Selimbur Caye as the basis of analysis. Output expected from this phase is the result of identification of social awareness values-related content contained in the subject matter given for each group. The third step is solving the problem. At this stage, students utilize the results of their explorations and analysis results to solve the social problems that have been presented in the first stage.

\subsubsection{Phase 4: Developing and Presenting Results}

In this phase, students, under the guidance of teachers, develop their exploration and analysis results in the form of a written report to be presented in front of the class. At the end of each presentation, the teacher facilitates students to conduct discussions, particularly related to the solution of previously presented social problems. Through this phase, each student is given the freedom to express their opinions, in accordance with their perspectives and data obtained. The role of teachers during this phase is as facilitator and mediator.

\subsubsection{Phase 5: Evaluation, Reflection and Reinforcement}

This phase is the last phase, before the class dismissal. There are three things done in this phase, namely evaluation, reflection, and reinforcement. Evaluation is the process where the teacher provides answers or clarifications related to questions that have been a controvercy during the discussion. Then, reflection is an activity where teachers and students jointly reflect on themselves, ie the extent to which they have applied the oral traditions of Selimbur Caye in daily life. For students, this activity is done by filling in a number of reflective questions that have been prepared. After that, the teacher gives reinforcement, in which the teacher invites or encourages the students to jointly apply the values of Selimbur caye oral tradition in everyday life.

\subsection{The Efectiveness of History Learning Based on Selimbur Caye Oral Tradition in Enhancing Student's Social Awarennes}

To see the effectiveness of the lessons learned in improving students' social awareness, a test is conducted. In this phase, the research design used is quasi experiment. The class positioned as experimental group is Class $X$ social science 1 while the control group is class $X$ social science 2 . In this test, the data used are post-test result of the experimental and control group. The effectiveness analysis was conducted by using independent t-test using SPSS version 23.

However, the data should be normally distributed and homogeneous before independent $t$-test was conducted. In the normality test, the result of significance of experimental class is 0.200 while control class is 0.140 . It means that the data of the two groups are normally distributed as the level of significance is greater than $0.05(0.200>0.05$ and $0.40>0.05)$. In the homogeneity test, the significance value obtained is 0.371 . The data is categorized as homogenous since the level of significance is greater than $0.05(0.371>0.05)$.

In the final process, the effectiveness was, then, analyzed. From the analysis, it was obtained the level of significance of (0.000) for the experimental class. It means that the two classes are categorized as having significant differences due to the level of significance is smaller than $0.025(0.000<0.025)$. Thus, it can be concluded that learning history based on Selimbur Caye oral traditions values is proved effective in increasing students' social awareness. 


\section{Conclusion}

Based on the result of research, several conclusion can be drawn. First, Selimbur Caye oral tradition is a form of local wisdom of Pasemah people in Bnegkulu which is full of values, especially, ones related to social life. Regarding the internalization of Selimbur Caye values in history learning, the combination of Problem Based Learning and Value Clarification Technique is very appropriate strategy to be taken into account. Second, it is also shown that the implementation of history learning based on Selimbur Caye oral tradition values is proved effective in enhancing students' social awareness.

Therefore, in the effort to prorect ourselves from the negative impact of globalization and in the process of students' character shaping, especially trough history learning, various forms of local wisdom in every region are very potential to be utilized. Specifically for schools in Pasemah Bengkulu, Selimbur Caye oral tradition is one of local wisdom that should be considered to be implemented in learning process.

\section{Acknowledgment}

This artickle is part of my Master Thesis which in the process of the research was funded by LPDP (Indonesian Ministry of Finance). Thus, I would like to deliver my sincere thank to them for the funding support.

\section{References}

Abdullah, I. (2006). Konstruksi dan Reproduksi Kebudayaan. Yogyakarta: Pustaka Pelajar.

Adisusilo, S. (2013). Pembelajaran Nilai Karakter, Konstruktivisme dan VCT Sebagai Inovasi Pendekatan Pembelajaran Afektif. Jakarta: PT Raja Grafindo Persada.

Boli, J \& Lechner, F. J. (2012). Teori Globalisasi. Dalam Bryan S. Turner (ed). Teori Sosial: Dari Klasik Sampai Postmodern. Tranlated by E. Setiyawati A \& Roh Shufiyati. Yogyakarta: Pustaka Pelajar.

Creswell, John W. (2003). Research Design: Qualitative, Quantitative, and Mixed Methods Approaches. Los Angeles: SAGE Publications.

Elmubarak, Z. (2009). Membumikan Pendidikan Nilai: Mengumpulkan yang Terserak, Menyambung yang Terputus, dan Menyatukan dan Tercerai. Babdung: Alfabeta.

Hannerz, U. (1990). Cultural Complexity: Studies in the Social Organization of Meaning. New York: Columbia University Press.

Hasan, S. H. (2012). Pendidikan Sejarah Untuk Memperkuat Pendidikan Karakter. Paramita: Jurnal Sejarah dan Pembelajaran Sejarah, 22 (1): 81-95.

Huda, C. (2013). Model-Model Pengajaran dan Pembelajaran: Isu-Isu Metodis dan Paradigmatis. Yogyakarta: Pustaka Pelajar.

Johnson, R. B \& Onwuegbuzie, A. (2004). Mixed Methods Reseacrh: A Research Paradigm Whose Time has Come. Educational Researcher, 33(7): 14-26. 
Lickona, T. (2012). Educating for Character. Translated byJuma Abdu Wamaungo. Jakarta: Bumi Aksara.

Mubah, A. S. (2011). Revitalisasi Identitas Kultural Indonesia di Tengah Homogenitas Global. Global \& Strategis (Special Edition), 251-260.

Wineburg, S. (2006). Berpikir Historis: Memetakan Masa Depan Mengajarkan Masa Lalu. Translated by Masri Maris. Jakarta: Yayasan Obor Indonesia.

Syaputra, E, Sariyatun, \& Sunardi. (2017). Socio-Cultural Values of Selimbur Caye Oral Tradition in Pasemah Ethnic Bengkulu. Advances in Social Science, Education and Humanities Research (Assehr), 158: 228-236.

Syaputra, E. (2017). Model Pembelajaran Sejarah Berbasis Nilai Tradisi Lisan Selimbur Caye dengan Paradogma Pedagogi Kritis untuk Meningkatkan Kesadaran Sosial Peserta Didik. (Unpublished Master Thesis). Pascasarjana Universitas Sebelas Maret.

Rai, R. (2014). Comparative Effectiveness of Value Clarification and Role Playing Value Development Models for Selected Values for Primary School Students. Journal of Humanities and Social Science, 19 (1): 28-34.

Sanjaya, W. (2011). Strategi Pembelajaran Berorientasi Standar Proses Pendidikan. Jakarta: Kencana.

Wilkerson, L., \& Gijselaers, W. H. (1996). Concluding Comments. In L. Wilkerson \& W. H. Gijselaers (Eds), Bringing Problem-Based Learning To Higher Education: Theory And Practice. San Francisco: Jossey-Bass. pp. 101-104.

Winter. (2001). Problem Based Learning. Speaking of Teaching, 11 (1): 1-8.

\section{Copyrights}

Copyright for this article is retained by the author(s), with first publication rights granted to the journal.

This is an open-access article distributed under the terms and conditions of the Creative Commons Attribution license (http://creativecommons.org/licenses/by/4.0/). 